\title{
The design process seen through the eyes of a type designer
}

\author{
Sofie Beier, \\ The Royal Danish Academy of Fine Arts, School of Design
}

\begin{abstract}
To understand how the design process works, the paper takes the outset in the work of one of the first innovating type designers: the English printer and typefounder John Baskerville (1706-1775). By comparing his way of working with a model for a contemporary design process, the paper reflects upon the relationship between this and the way Baskerville might have worked in the development of his historical typeface style.
\end{abstract}

Keywords: Type design, type history, design thinking, design process, John Baskerville

\section{INTRODUCTION}

As a young designer I had the understanding that great ideas are something that falls into the lap of the lucky few creative souls. I thought it was a mysterious process full of unidentifiable variables, which these people would operate between in an effortless manner while they awaited that the pieces of the puzzle would fall naturally into place. I now understand that it is not quite so. In most cases,

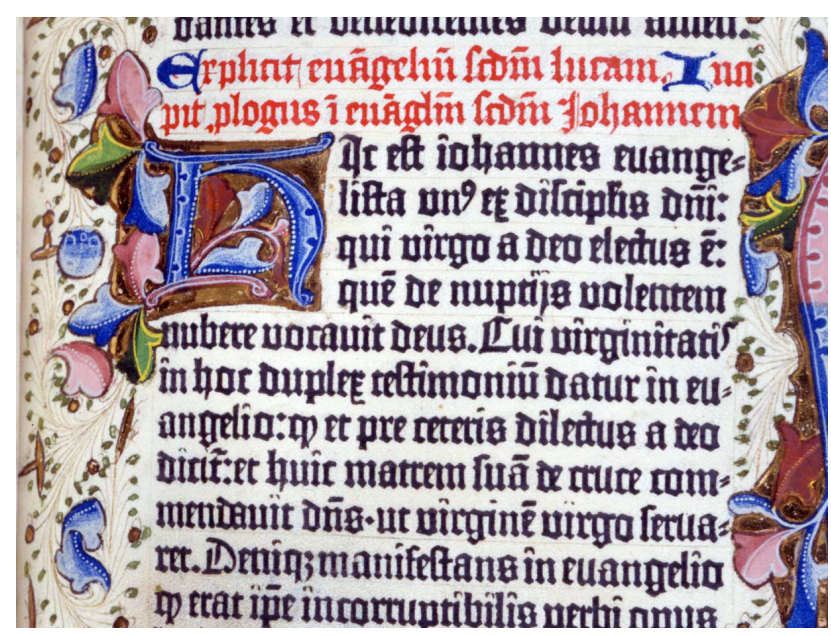

Figure 1. Gutenberg Bible of 1455. innovating design will be based on a thorough methodology and hard work. What is even more amazing is that this is a method that can be learned.

From my vantage point in contemporary design theory, I will look into the historical figure of John Baskerville-in my view one of the first typographers who produced innovative design solutionsand reflect on how he might have worked in his process of designing. To describe the period in which he was working and to explain what the tradition was before, I will on a more general level discuss some of the most central figures of the history of typography.

\section{THE EARLY TYPEFACES}

The idea that good design is synonymous with great concept development was not always part of the typographical culture. In the early days of printing, the notion of a successful typeface was something very different.

When Johannes Gutenberg (1395-1468) launched his movable type, he based his fonts on an existing writing hand (Figure 1). In doing so, he applied a method that is still in use today: whenever a new medium comes into play, the form language adapted to this medium will initially follow the form language of previous technologies. ' Gutenberg furthermore imitated the page layout developed by the scribes as evident in the initial letters, which he subsequently had hand colored in the fashion of the scriptoriums.

When printers in Italy a few years later took up the printing of the Roman alphabet, they too based the first printed pages on what was en vogue in the calligraphic school - the rediscovery of the Carolingian Minuscule. They did this for several reasons. For one, the contemporary reader was already familiar with reading handwritten scripts, and consequently this was their preferred typographical style, and secondly, the new printed books were seen as 
rofffimiofculamentidequel Quoufque tandem abutere, il feruato ordine, ilqualeeffac patientia noftra? quamdiu rato cum miro \& amorofo fo furor ifte tuus eludet? quen Itra finaal prafentecalo, Onc fefe effrenata jactabit audac fa\&prafidentedequeftolocc ne te nocturnum præfidiu. mentedediuertire, obliquare nihil urbis vigiliæ, nihil tim. reil bene, Etle humile \& ime, nihil confenfus bonorum on cire.Leobfcurelucificare, \&l hil hic munitiffimus haben

Figure 2: The Hypnerotomachia Poliphili of Aldine Press from the year 1499 (left), and William Caslon's Paragon cut from the year 1764 (right).

inferior to the competing handwritten manuscripts, as evidenced by the following quote from the latter part of the 15th century, where a bookseller of Florence discusses the content of a specific library:

In this library all the books are superlatively good, all are written with the pen; and were there a single printed book it would have been ashamed in such company. All are most beautifully illuminated and written on vellum. (Morison, 1949, p. 21)

Several of the printers had a background in the fields of goldsmith or gunsmith. It is likely that they viewed themselves as craftsmen with the goal to copy and improve on the successful type developed by their predecessors. The outcome was that the style of typography stayed remarkably the same for the first 300 years of printing (Figure 2). An example of this culture is shown in an epistle by the famous French typefounder Claude Garamond (ca. 14801561), where he refers to a conversation with an acquaintance about the work of a famous Italian foundry:

He [the acquaintance] declared that the best way of starting would be to cut as soon as possible new types after the italic letter of Aldus Manutius [...] So I engraved italic types after the model of the Aldine, with what success others will judge. (Johnson \& Morison, 1924, p. 49)

The way he mentions his sources indicates that Garamond did not see himself as an inventor of new typographical solutions; his aim was to follow the tradition established by others, and then improve on this.

The first indication that things were about to change came with the Romain du Roi plates. Made by a committee appointed in 1692 by the French king Louis XIV, the development and production period lasted until 1745. It is the first documented example

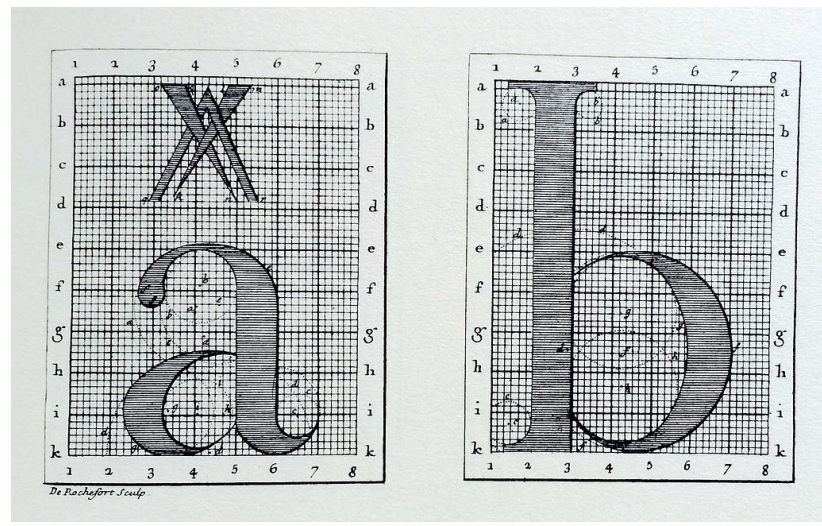

Figure 3: Examples of the lowercase Romain du Roi plates.

of a typeface that is based on a thorough investigation with the committee members spending a significant amount of time researching letter and type production of previous generations (Jammes 1965). The final plates that were to function as a model for the punches were engraved on a delicate structured grid (Figure 3). For the first time in history, a new typeface had been exposed to a thorough developmental process, and the final product looked like nothing seen before in printing.

None of the members of the Romain du Roi committee worked in the printing industry: they were scholars and left the production of punches and later the printing of the type to others. One of the first examples of someone within the field that was clearly aiming at producing new solutions is the Englishman John Baskerville (1706-1775). Baskerville spent seven years developing his type (Pardoe, 1975, p. 24). Baskerville was an outsider as he came from the trade of japanning ${ }^{2}$ where he had made a substantial fortune; a fortune which he invested in his new printing project. He further had a background as stone carver and writing-master, and therefore had a somewhat different starting point than his peers and predecessors. His aim was to change the overall look and feel of the printed page (Pardoe, 1975, p. 27-28). This he did by developing new kinds of paper and ink, and by designing a new typeface style that was influenced by contemporary calligraphic writing hands (Warde, 1927, p. 12). Baskerville did so in contrast to his competitor William Caslon (1692-1766) who was focusing on improving the work of previous punch-cutters, and did so with great success (Denman, 1955, p. 101-2). In basing his types on contemporary writing hands, Baskerville was, now many years later, recovering the method of the early Renaissance printers and using this to change the direction of typography. Beatrice Warde $(1927$, p. 12) has pointed out that 
fo Ludere, quæ vellem, calamo permifit agrefti. $M$. Non equidem invideo; miror magis : undique totis Ufque adeo turbatur agris. en ipfe capellas Protenus ager ago: hanc etiam vix, Tityre, duco:

Hic inter denfas corylos modo namque gemellos,

Baskerville was the first typefounder of his era that took inspiration from the calligraphic trade, and that he did this at a time where the calligraphic culture of using a pointed nib pen had been en vogue for at least half a century. It is an interesting observation that in this period, printers had lost any connection to type as originating in the writing hand; the predominant course of action was instead to refine the already existing type, and it took this long before any type creator came up with the idea of drawing on inspiration from the new developments in the field of calligraphy. Warde further praised Baskerville for his courage in daring to break with this fashion in the printing industry where she found that "abstract rules still were applied to works of beauty-due to over-respectful study since the renaissance of didactic Roman text-books" (Warde 1927, p. 12). The big difference between Baskerville and the early printers was that Baskerville was breaking with the norm of his contemporaries, while the early Renaissance printers obeyed the norm of their contemporaries by incorporating calligraphic references. Not only did Baskerville develop new paper, ink and type, he also introduced a novel page layout of large margins, wide spaced text, and no ornaments, which at the time must have appeared highly radical (Figure 4).

\section{Following Herbert Simon's definition that}

"[e]veryone designs who devises courses of action aimed at changing existing situations into preferred ones" (Simon, 1988, p. 67), it is clear that Baskerville stands out from the previous typographers in wanting to change "existing situations" through the development of something new. As demonstrated in the following quote from a letter written by Baskerville to the Royal Academy of Science in Paris, Baskerville found it important to emphasis this distinction:

\begin{abstract}
You will at a Glance observe, that my Letters are not (one of them) copyed from any other; but are wrought from my own ideas only. (Straus \& Dent 1907, p. 105)
\end{abstract}

Others soon followed in Baskerville's footsteps: Giambattista Bodoni (1740-1813) in Italy was highly influenced by Baskerville's work in his early carrier, and like the Didot family in France, Bodoni later designed typefaces in the Modern tradition. The first typefaces of these publishers had the look and feel of other contemporary typefaces, but over the years their work developed into novel typeface styles inspired by copperplate engravings mixed with a constructed and modular feel. The change of style was truly significant, indicating that both Bodoni and the Didot family had developed a process involving a significant amount of experimentation and try-outs in the production (Figure 5).

The very early printers were tradesmen. They practiced their craft with great pride, making an immense effort to produce beautiful and functional typefaces; they focused on developing punches that printed clear and legible type on the page. They were highly skilled craftsmen, but not designers in Herbert Simon's understanding of the term. With John Baskerville came a shift in focus: now the purpose was not only to communicate the content of the text in a traditionally legible typeface, the type should also play the role of visualizing the emerging Neoclassical movement.

In modern day graphic design, the work of Baskerville is considered a classic. On several occasions, the famous graphic designer Massimo Vignelli (1931-2014) stated that he did not need more than a dozen typefaces, as he found that "in reality the number of good typefaces is rather limited and most of the new ones are elaborations on pre-existing faces" (Vignelli, 2010, p. 54). On Vignelli's list is the 

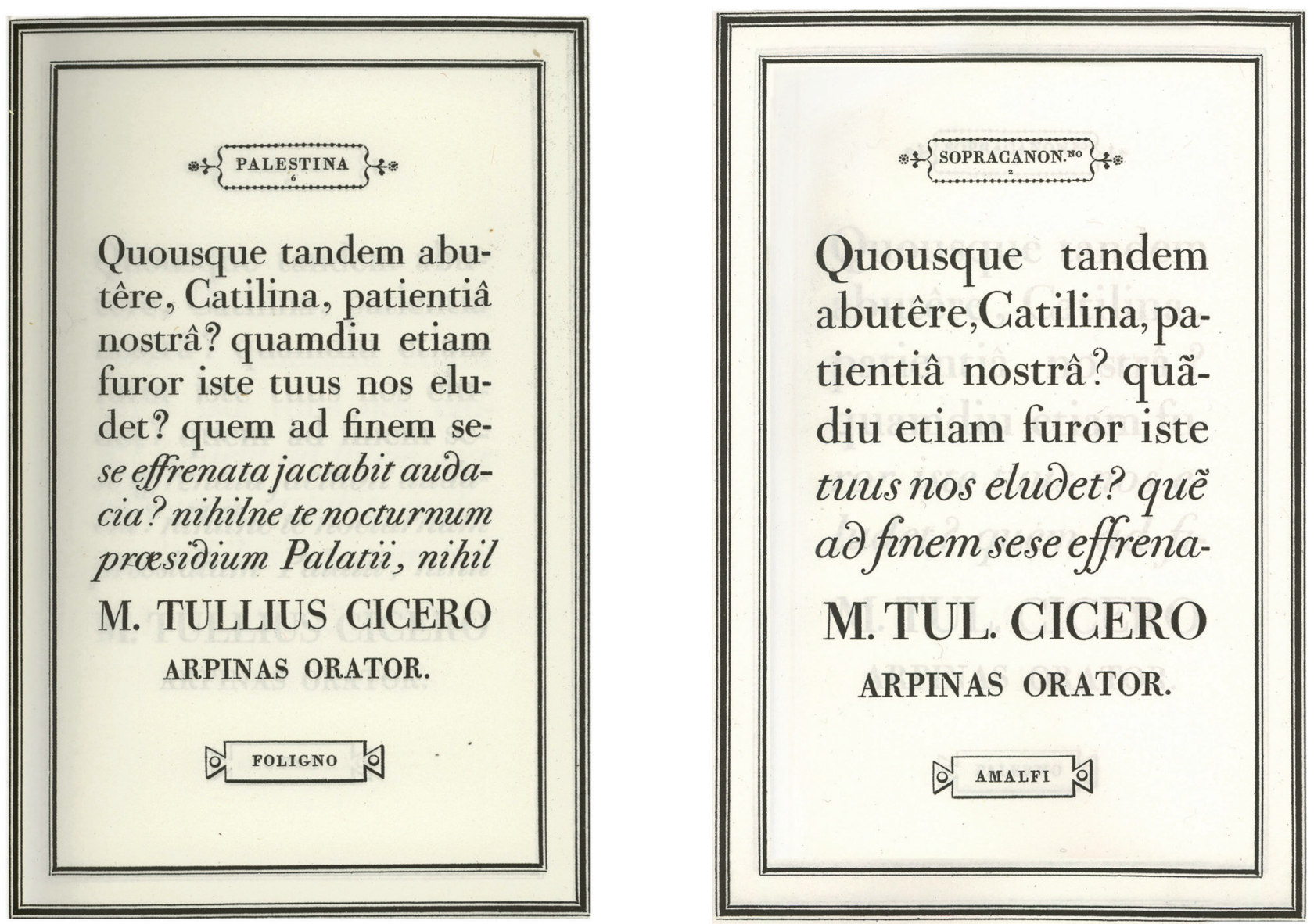

Figure 5. The grant collection of Bodoni's work, finalised by his widow Margherita after his death (Bodoni 1818), demonstrates the range of variations he created in a constant search for new directions to move his own typographical language.

type of Baskerville. The popularity of Baskerville's work is further demonstrated by the more than 30 available digital revivals, among these, the highly popular typeface family Mrs Eaves by Zuzana Licko, which-according to its publisher-has outsold all their other fonts by twofold (Emigre, 2013).

How did Baskerville manage to develop innovative designs? Did he apply a work method similar to that defined in present day design theory, or did the ideas just come to him? Taking my departure in what we know from John Baskerville's seven years developmental phase, I will in the following compare Baskerville's way of working with a contemporary model for a design process.

\section{THE DESIGN PROCESS}

Based on the term "direction of fit" proposed by philosopher John Searle (2005), Ann Heylighen and her colleagues (2009) have offered a detailed description of how the focus of the different stages in the design process changes between a world-to-mind (imagination) and a mind-to-world (evaluation) direction of fit. In the former, the focus is inwards, making the design match the designer's idea about the world, while in the latter, the focus is outwards investigating how the idea fits into the world. If the design process is solely based on the imagination of the world, the product risks being a personal experiment with no relevance to others; then again, if the process solely focuses on the evaluation of the world, the creative aspect will suffer and the final product would likely contain a minimal amount of original material. By shifting the direction of fit back and forth, the designer ensures that the product will be both valid and relevant for the purpose.

Most theorists in the field of design thinking agree that it is possible to create some form of a model that describes the various stages of the design process. The different models proposed vary in the details; some being more focused on prototyping (Nini ,2006; Cooke, 2006), others having a greater emphasis on the evaluation (Lawson 2005), and others again following different teaching approaches 
(Beier, 2014). The general take is, however, that the design process is structured so that it includes different working strategies with each stage having its own focus, and that these stages are interconnected and should be viewed as vital parts of a whole. For this paper, I follow the same division of the stages as applied by Beier (2014), and have divided the design process into the four stages of: Specification, Analysis, Creating, and Form Making.

\section{Stage 1: Specification}

At the first stage of designing, the task is to identify all aspects of the problem at hand. This is the moment to identify the "existing situation" that needs to be changed into a preferred one (Simon 1988), as the designer combines his or her own experiences and understandings of the problem, and through that specifies the starting point of the project. Nigel Cross $(2007$, p. 24) has emphasized that design problems by nature are ill defined, as not all are solvable. It is impossible to find adequate answers to all possible questions. The designer will need to apply a working method that accommodates a certain level of constant uncertainty.

John Baskerville intended to produce a new style of printing type; his type should be different from anything seen in print before (Baskerville 1758, p. A3). His aim was to produce a typeface that stood clear on the page with a high contrast between the black and white colors. In a letter to a London bookseller in 1752, accompanying a specimen of some of his newly finished work, Baskerville stated the following about the type:

I can't forbear saying they please me, as I can make nothing more correct, nor shall you see anything of mine much less so. You'll observe they strike the Eye much more sensibly than the smaller Characters tho Equally perfect, till the press shows them to more Advantage. The press is creeping slowly towards perfection; I flatter myself with being able to print nearly as good a colour \& smooth a stroke as the inclos'd. (Pardoe, 1975, p. 23)

It was essential to him that his type should embody an elegance that exceeded any work of his contemporaries. This was his clear specification, and supposedly, this was what kept him going throughout the seven years of hard work.

\section{Stage 2: Analysis}

At the analysis stage, the designer no longer is focused on his or her own experiences and opinions, but instead focuses on how the project fits into the world. In addition to traditional information gathering such as literature and online searches, and to the identification and analysis of similar projects, the designer will be further informed on the objectives by carrying out various forms of audience research. Nini (2006) suggests three different methods for this, one being surveys of questionnaires and interviews, another being behavioral research of observing the design in use, and the third being participatory research where the user is involved in the development of the product.

The way the designer chooses to implement these findings in the process is essential for how much it eventually will inform the project. In a controlled experiment, Nigel Cross and colleagues (1994) found that the students who applied a work method of shifting rapidly back and forth between the information and the evaluation of the information, also were the ones who produced the most successful designs. While gathering new material, it is crucial to continuously structure the information and to look for patterns. The designer who starts out by first collecting all the information that springs to mind and then sits down to evaluate its importance will most likely end up considering the majority of the findings as irrelevant for the final solution.

Baskerville's analysis was most likely based on close visual inspections of calligraphic writing hands and on printed books. His main inspiration came from the contemporary calligraphic culture of the pointed nib pen, while he used his study of the printed books to understand his competitors' work. Baskerville's goal was to "obtain a 'reputation of excelling in the most useful art known to mankind'" (Straus \& Dent 1907, p. 102). There is no record indicating that he made use of any form of modern-day audience research. Had he asked for the opinion of his peers, he would most likely have received a somewhat negative feedback. Although he later found praise for his work abroad, the opinion among several British printers was that Baskerville was a silly amateur that should know his place (Beier, 2012, p. 164; Dreyfus, 1994, p. 19).

\section{Stage 3: Creating}

Exploration and creative thinking dominates this next stage of the process. At this point, the designer will generate a response to the defined problem using the designer's own imagination. To motivate the creative thinking, Lau and colleagues (2009) describe a number of thinking techniques that all facilitate a shifting perspective on the project through divergent thinking. Another way of shifting perspective is to apply the mental operation of Conceptual Blending; proposed by Fauconnier and Turner (2002; 2003), the idea is to combine elements from within 
two matters that normally do not have a natural relation, and by doing so, produce a novel unexpected angle on the project. This method has often been used in the fashion industry. An example is the London based fashion designer Makin Jan Ma, who creates garments to the characters of a fictitious film project. The conceptual blending happens here in the dialogue between the unrelated matters of cloth and story line.

In the whole design process, this is the point that is influenced the most by uncertainty. Although occasionally frightening, it is according to Hall (2011, p. 21) in fact desired, as the lack of control brings on a certain kind of coping strategy that can lead to great insight and innovative combinations of elements. At this point of the process, hand sketching will provide the designer with a unique opportunity to carry out a discussion with one's self, and to facilitate a critical evaluation of the different solution attempts, which then can be held up against the various objectives identified in the analysis stage. Through sketching, the designer can try out the validation of an idea, and reflect on all the possible angles to see which is the strongest. When working on multifaceted projects, sketching further allows for more aspects to be visible at once, and to maintain an overview of the complexity, while keeping focus on all critical details that will need to be reworked. By doing so, the designer will be able to move up and down in the level of complexity of the overall project.
Baskerville drew on a kind of inspiration that none of his contemporaries did. He would apply a method of conceptual blending by drawing on elements from within two unrelated matters: calligraphy and printing type. The nature of the blend was so that he drew on the visual features of the calligraphic letters, and combined these with the media of print. All the shapes of Baskerville's type can be created with the pointed nib pen (Figure 6); knowing that Baskerville was a writing-master, the pointed nib pen must have been his preferred sketching tool in the exploration of the letter shapes.

\section{Stage 4: Form Making}

Occasionally, when the designer reaches the Form Making stage, all major decisions and reflections on ideas and strategies have been made. In such rare situations, the designer will be able to dig into the world of creating beautiful and harmonious shapes and forms. Yet, in most projects, aspects of form making will have a significant influence on all the stages of the process. What really separates this stage from the previous stages is the central influence of the craft. In most fields within design, successful form making is closely tied to mastering the skills of the trade. The furniture designer needs to know how the wood behaves when bent, the fashion designer needs to understand the nature of the drape, and the type designer needs to understand the balance between the inner and outer shapes of the letters. These trades are all heavily influenced by tacit knowledge gained through practice, and

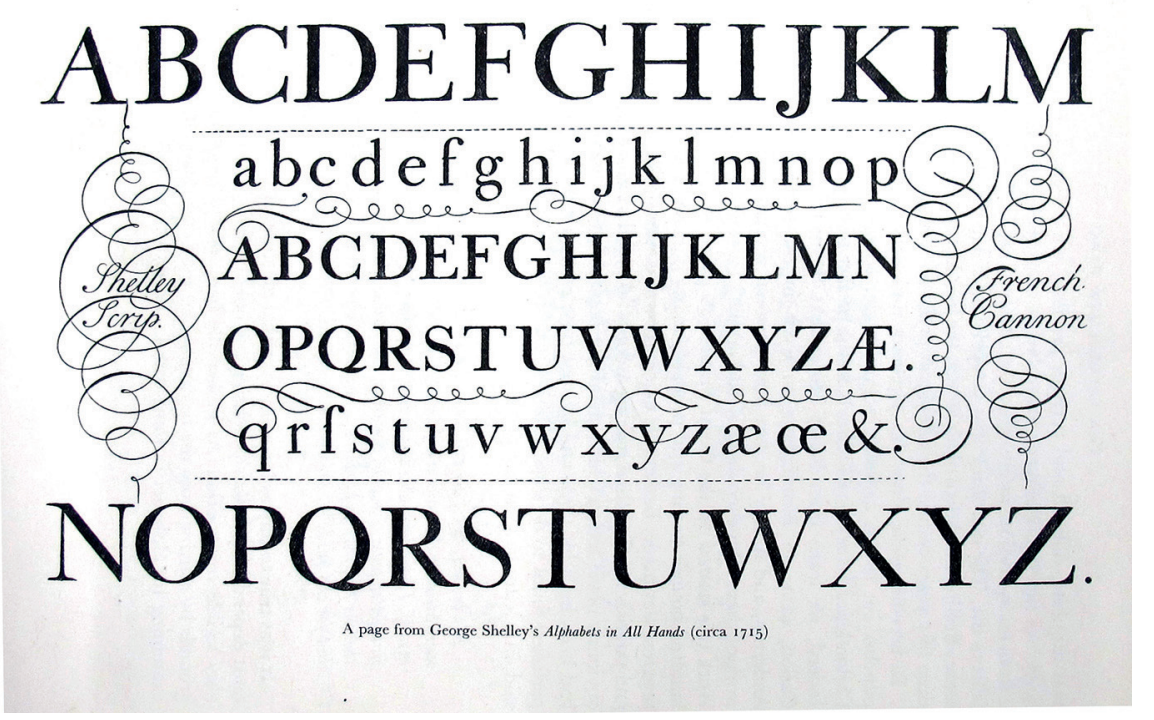

Figure 6. Baskerville was inspired by this calligraphic style of writing from around 1715 (by the writing-master George Shelley). 
by specific rules of the trade that can be learned through a master-apprentice relation, or through trial and errors.

Although Fred Smeijers (1996) has thoroughly demonstrated how punch-cutters produced their punches, we know very little about the nature of the preliminary sketching process. Keeping in mind that Baskerville had a background in calligraphy and that he wanted to excel in the trade, it is likely that in the refinement of the letter shapes, Baskerville would first write the letters, and then provide these calligraphic sketches as models for his punch-cutter John Handy, who then would cut trial-punches and interpret the letters so that they would function at the specific sizes of the press. Following Baskerville's corrections, Handy would then produce new takes on the punches, which Baskerville would correct and so on. In this way, the Creating and Form Making stages were interconnected, and Baskerville likely viewed them as one.

\section{THE PRACTICAL IMPLICATIONS OF THE MODEL}

Every designer has their own variation of the design process; the more experienced the designer is, the more the design process will turn into an intuitive operation where the designer freely shifts back and forth between stages. Although most projects will begin with the Specification stage and end with the Form Making stage, designing rarely happens as a series of sequential stages, it is a messy organism that will contain a number of return loops from one stage to the previous as the project gradually becomes more and more informed. It is, for example, difficult for the designer to fully specify the project angle at the Specification stage, before investigating the problem at the Analysis stage; this jumping mechanism is essential to benefit from anything learned. As discussed above, rapid shifts between the gathering of information, located at the Analysis stage, and reflection concerning its value, located at the Creating stage, is further essential to insure that the material found through analysis will be of use. As the designer shifts between the stages of Analysis and Creating, he or she will simultaneously learn about the nature of the design problem, and gain a broader understanding of all possible solutions. Occasionally, the designer will have to produce some form of solution before truly understanding all aspects of the design problem. In such cases, the designer will have to move the whole way back to the Specification stage and re-define the problem.
In spite of the difference ways designers approach the task of designing, I believe that central to all great design projects is: a specification of the intentions; knowledge of the relation to the world; an exploration of alternative angles and viewpoints; and an understanding for the craft of the field. John Baskerville followed these stages in his own work process; it is, however, unlikely that he would have been able to explain it, as it probably was happening instinctively. By bouncing Baskerville's working method against contemporary design theory, it ironically demonstrates that you do not have to be schooled in the design process to be a successful designer. However, Baskerville reached his goal through seven years of hard work. It is an interesting thought experiment, how quickly he would have attained a satisfactory result, had he been educated in the modern understanding of an effective design process.

\section{NOTES}

1. Other examples of this: 1) Many early web pages looked like printed pages; and 2) in early talking movies, actors often applied the highly animated acting style adapted from silent movies.

2. Japanning is a European imitation of Asian lacquer-work. It is based on a heavy, often black lacquer that almost looks like enamel paint.

\section{REFERENCES}

Baskerville, J. (1758). Preface. In John Milton: Paradise lost (p. A3), printed by John Baskerville Birmingham.

Beier, S. (2012). Reading letters: designing for legibility. BIS Publishers.

Beier, S. (2014). A stage-based model of design teaching. Art, Design \& Communication in Higher Education, 13(2), 157-174. http://dx.doi.org/10.1386/adch.13.2.157 1

Bodoni, G. (1818). Manuale tipografico. Parma: Presso la Vedona.

Cooke, M. (2006). Design methodologies: towards a systematic approach to design. In A. Bennett (Ed.), Design studies: theory and research in graphic design (pp. 130-146). New York: Princeton Architectural Press.

Cross, N. (2007). Designerly ways of knowing. Basel: Birkhäuser.

Cross, N., Christiaans, H. \& Dorst, K. (1994). Design expertise amongst student designers. International Journal of Art \& Design Education, 13(1), 39-56. http://dx.doi. org/10.1111/j.1476-8070.1994.tb00356.x

Denman, F. (1955). The shaping of our alphabet. New York: Alfred A. Knopf.

Dreyfus, J. (1994) Into print: selected writings on printing history, typography and book production. London: British Library. 
Licko, Zuzana (2009). Mrs Eaves XL [font]. Retrieved from http://www.emigre.com/EF.php?fid=212.

Fauconnier, G. \& Turner, M. (2002). The way we think: conceptual blending and the mind's hidden complexities. New York: Basic Books.

Fauconnier, G. \& Turner, M. (2003). Conceptual blending, form and meaning. Recherches en communication: sémiotique cognitive, 19, 57-86.

Hall, A. (2011). Experimental design: design experimentation. Design Issues, 27(2), 17-26. http://dx.doi.org/10.1162/ DESI a 00074-Hall

Heylighen, A., Cavallin, H., Bianchin, M. (2009). Design in mind. Design Issues, 25(1), 94-105. http://dx.doi.org/10.1162/ desi.2009.25.1.94

Jammes, A. (1965). Académisme et typographie: The making of the Romain du Roi. Journal of the Printing Historical Society, 1,71-95.

Johnson, A.F. \& Morison, S. (1924). The Chancery types of Italy and France. The Fleuron, 3, 23-51.

Lawson, B. (2005). How designers think: the design process demystified. Oxford; Burlington, MA: Elsevier/Architectural Press. (Original publication, 1980).

Lau, K.W, NG, M.C.F., Lee, P.Y. (2009). Rethinking the creativity training in design education: a study of creative thinking tools for facilitating creativity development of design students. Art, Design \& Communication in Higher Education, 8(1). http://dx.doi.org/10.1386/adch.8.1.71_1

Morison, S. (1949). Four centuries of fine printing. London: Ernest Benn Limited.

Nini, P. J. (2006). Sharpening one's axe: making a case for comprehensive approach to research in the graphic design process. In A. Bennett (Ed.), Design studies: theory and research in graphic design (pp. 117-129). New York: Princeton Architectural Press.

Pardoe, F.E. (1975). John Baskerville of Birmingham: letter-founder and printer. London: Frederick Muller Limited.

Searle, J.R. (2005). Mind: A brief introduction. 0xford: 0xford University Press.

Simon, H. (1988). The science of design: creating the artificial. Design Issues, 4(1+2), 67-82. http://dx.doi. org/10.2307/1511391

Smeijers, F. (1996). Counter punch: making type in the sixteenth century, designing typefaces now. London: Hyphen Press.

Straus, R. \& Dent, R.K. (1907). John Baskerville: a memoir. London: Cambridge University Press for Chatto and Windus.

Vignelli, M. (2010). The Vignelli canon. Baden: Lars Müller.

Warde, B. (1927). The Baskerville types, a critique. The Monotype Recorder, 221, 3-29.

\section{CORRESPONDENCE}

Sofie Beier, The Royal Danish Academy of Fine Arts, School of Design, Philip de Langes Allé 10, 1435

Copenhagen K, Denmark

E-mail: $\underline{\text { sbe@kadk.dk }}$
Published online 28 July, 2015

ISSN 1749-3463 print/ISSN 1749-3471

http://dx.doi.org/10.14434/artifact.v3i4.6199

(C) 2015 Artifact

Copyright to illustrations in this article resides with the creator unless otherwise noted. Artifact publishes illustrations in accordance with commonly acknowledged fair use of visual materials for non-commercial research purposes. Creators who feel that publication is in violation of copyright or fair use should contact the editors. 